\title{
Modernisation, Urban Renewal and the Social Cost of Development
}

\author{
E.B.A. Agbaje, PhD. \\ Department of Political Sciences, Faculty of The Social Sciences, \\ College of Management and Social Sciences, Osun State University, Osogbo, Nigeria \\ E-mail: ebagbaje@yahoo.com; elijah.agbaje@uniosun.edu.ng mobile: +234-805-591-8422
}

\section{Doi:10.5901/mjss.2013.v4n10p318}

\begin{abstract}
Within the global development wave, urban renewal is seen as remedy to insecurity. Therefore, no reasonable government would leave strategic cities in disorder. But the question is: whose needs should first be addressed in acutely poor societies? Homelessness and hunger arising from demographic displacements and joblessness are the immediate result of urban renewal and genrification. 'The poor-indeed' bear most of the brunt. Almost all natural cities in the world are first established by 'the poor-indeed'. If modernization must force the poor out of their heritage, provision for resettlement should be made available, affordable and timely. Examining the displacements in places like Maroko, Lekki, other cities in Western Nigeria and the FCT, the welfare of the poor and menial workers, has been the social cost of development. With government acting as facilitators, the new occupants of the 'hijacked cities', though having the fund, neither have any link with, nor make any contribution to ease the resettlement plights of the displaced poor. The paper submits that development understanding in Nigeria has been elitist. It contends that with time, elite-fostering development that forsakes the plights of the 'poor indeed' will only serve to exacerbate insecurity. To be meaningful, development programmes for countries such as Nigeria where the wealth of the rich results from the poverty of the poor, should first seek to salvage the 'poor indeed' as current experience under some of the state governments.
\end{abstract}

Keywords: Urban renewal, modernization, gentrification, displacement, resettlement, the poor/the poor indeed, government, elites, Nigeria

\section{Introduction}

Africa is a region experiencing one of the fastest rates of urbanisation and associated challenges in the world, with subSaharan Africa leading the way. By 2030 Africa will have 760 million urban residents. By 2050 that figure is expected to grow to 1.2 billion (Siemens 2013). Nigeria, at present, is a typical theatre of urban transformation (Olukoya, et al 2012). Across Nigerian history of underdevelopment, the lot of the poor has been most negatively affected. Of all social classes, their interest has continued to be the opportunity cost of modernization. Due to elitist orientation of policies, the poor bear the brunt of development and their welfare shortchanged at the altar of political and economic opportunism. With Nigeria just attempting to foster democratic rule, it is envisaged that since the poor constitute the majority of the democratic social capital and expectedly the pillar of governance, their interest should count first in the planning and execution of development programmes. It is in the light of the above that this paper examines the recent efforts at modernization through urban renewal and its social cost in Nigeria.

\section{Review of Literature}

Historically, the policy of urban renewal and its associated gentrification, took place in ancient Rome and in Roman Britain the 3rd century, AD. One of the earliest urban renewal in the modern era took place in the United States with the federal urban renewal programme- the Housing Act of 1937, meeting the need of the lower-income group. In 1949 this was followed by a major rebuilding and displacement programme, which "allowed clearance of low-income housing and small buildings in downtown areas so that central business districts and public institutions could be expanded and enhanced" (sourced from: http://en.wikipedia.org/wiki/Public_housing_in_the_United_States on 6 July, 2013). This latter programme also initiated the first move towards provision for the assistance of persons displaced from their homes. Since then, every form of urban renewal has always resulted into displacement of people from their residential and economic base. It has always been the lot of the poor to be displaced. 
Gentrification has been considered as a multi-faceted phenomenon. British sociologist Ruth Glass who coined the term "gentrification" in 1964 used it to describe the influx of middle-class people displacing lower-class worker residents in urban neighborhoods, noting, that:

\begin{abstract}
Many of the working class neighbourhoods of London have been invaded by the middle-classes - upper and lower. Shabby, modest mews and cottages - two rooms up and two down - have been taken over, ... all or most of the original working-class occupiers are displaced and the whole social character of the district is changed (Ruth Glass 1964).
\end{abstract}

It has been argued from US experience that as "the transformation of neighborhoods from low value to high value occur, it brings along with it the potential to cause displacement of long-time residents and businesses... from a gentrified area because of higher rents, mortgages, and property taxes" (Centers for Disease Control and Prevention 2013). Apart from its demographic reconfiguration effect, urban renewal has also been found to have direct impact on economic and health, community's history and culture, and as well reduces social capital. As a politically charged variable, urban renewal and gentrification, according to Maureen Kennedy and Paul Leonard (2001), represent a "process by which higher income households displace lower income residents...". The American urban theorist John Friedman proposed a seven-part theory that bifurcated service industry in world cities. His analysis, which was further expanded by Sakia Sassen (2001), Atkinson et al (2005) and Jason C. Booza et al (2006), composed of:

\begin{abstract}
a high percentage of professionals specialized in control functions and ... a vast army of low-skilled workers engaged in ... personal services ... [that] cater to the privileged classes, for those whose sake the world city primarily exists". The final three hypotheses detail (i) the increased immigration of low-skill labourers needed to support the privileged classes, (ii) the class and caste conflict consequent to the city's inability to support the poor people who are the service class, and (iii) the world city as a function of social class struggle (Fiedman 1986).
\end{abstract}

This study finds relevance in the analysis of urbanization and gentrification by London and Palen (London and Palen (1984) to explain the roots and the reasons behind the spread of urban renewal and associated dynamics in Nigeria. London and Palen (1984) proposed a list of five approaches for analysis of urbanisation and gentrification: (1) demographic-ecological, (2) sociocultural, (3) political-economical, (4) community networks, and (5) social movements.

The first theory, demographic-ecological, attempts to explain gentrification through the analysis of demographics: population, social organization, environment, and technology. This approach was premised on the growing number of people in the 1970s, or the baby boom generation. In Smith's analysis, the population boom, led to increase demand for housing as more affluent people having white-collar jobs wanted to live closer to work. The result was that the cities had to and were "recycled" to meet such demands (London and Palen, 1984). Hence the submission by Smith (1987) that gentrification is a structural economic process, and Ley's explanation that gentrification is a natural outgrowth of increased professional employment in the central business district (CBD) were well reasoned. From this study, it was shown, just as it is presently occurring in Nigeria, particularly in state capitals and the federal capital territory, that the relationship between administrative activity and invasion by the upper class and displacement of the poor were positively correlated.

The second theory proposed by London and Palen, based on a socio-cultural explanation of gentrification, is also relevant in the Nigerian context. This approach argues that values, sentiments, attitudes, ideas, beliefs, and choices should be used to explain and predict human behavior, (London and Palen 1984). This analysis focuses on the changing attitudes, lifestyles, and values of the middle- and upper-middle-class who were becoming more pro-urban than before. These "urban pioneers" saw the inner-city as an "appropriate" and "viable" place to live, resulting in what is called "inner city chic" (London and Palen 1984). However, just as the political-economic variant will argue, for Nigeria, much of this displacement is facilitated with state resources (power, finance and communication) all of which lies at the disposal of the elites to the detriment of the poor. In Nigeria, the urge by the elites to live in the city is more compelled by the fact that, apart from the added automated boundless opportunities provided by the current techno-com-spheres, it is at the cities (seat of powers) that the wealth of the nation is administered and shared.

According to London and Palen, "powerful interest groups follow a policy of neglect of the inner city until such time as they become aware that policy changes could yield tremendous profits" (London and Palen 1984); aided by technological advances (Greer, 1962), once the inner city becomes a source of revenue, the powerless residents are displaced with little or no regard.. In Nigeria, the influence of the so-called ideological successful urban pioneers, politicaleconomic elites, land developers, speculators, and lending institutions who are staunch supporters of ruling governments 
have been noticeable in planning and enforcement of urban renewal. Displacement as experienced in Maroko and Lekki, most often for political, economic and administrative gains of the elites forsakes the interest of the poor.

As a back-up to the above, rent-gap theory describes the disparity between "the actual capitalized ground rent (land price) of a plot of land given its present use, and the potential ground rent that might be gleaned under a 'higher and better' use" (Smith 1987) as basis for urban renewal. Smith, in his analysis, has shown that:

\begin{abstract}
Rent gap is fundamental to explaining gentrification as an economic process. When the gap is sufficiently wide, real estate developers, landlords, and other people with vested interests in the development of land perceive the potential profit to be derived from re-investing in inner-city properties and redeveloping them for new tenants. Thus, the development of a rent gap creates the opportunity for urban restructuring and gentrification.
\end{abstract}

This approach, also has found expression in some of the urban renewal programmes that have taken place in Nigeria. The case of Lagos and other state capital cities best illustrate this (Olawepo 2008:273-287). With dwindling revenues accruing from crude oil and the urge to increase internal generated revenues, state governments have resorted to reclaiming lands and properties hitherto neglected or under-utilized for higher economic use and returns. Revenue accruing from land use, usually referred to as tenement rates, has become a major source of added revenue to state governments in Nigeria. Response from the poor to urbanization and gentrification also varied in history and across spaces. While in some instances it propelled class conflict sometimes involving vandalism and arson targeting the property of the elites; and in others, establishment of inclusionary zones to accommodate the interest of the poor. With the low level of education and right advocacy, regrets and lamentations by the poor has largely been the order in Nigeria.

Reviewing the existing order on urbanization in Nigeria, analysts (Sani, Green, Udenta, Ugwu and Uyanga), have shown that urban development, renewal and administration are connected to several networks of political institutions, socioeconomic services, and are urban-based, affecting "the whole range of governmental organization and processes" (Green 2011). Except in unique circumstances, this often present some profound goal conflict (Udenta 2011). According to analysts, urban policies should strengthened public institutions which deliver services such as transportation, employment, health, education, sanitation rather than those that enable commodity producers to accumulate more capital (Idise 2010; Ugwu 2011; Uyanga 2011). They should also be:

\begin{abstract}
designed to tackle the problems of urban centers and small urban centres side by side with rural development and government institutions are expected to conform to the national development strategy that are intended to achieve specific objectives (Cohen 2011).
\end{abstract}

In sum, comprehensive and coherent urban policies must clarify the appropriate role for the government with a focus on the imperative to improve the quality of both indigenous and new urban institutions and achieve minimum welfare of the poor. Non-achievement of these objectives, particularly in Nigeria, has been traced to poor, misplaced and ill-conceived conception and delivery of programmes by governments informed by the disguised 'motives of the cult of elites' for capital accumulation and self-aggrandizement.

While most approaches, planning and execution framework sees urban renewal or gentrification from the elitist viewpoint, the current experience in the State of Osun in Nigeria seem to offer some new and positive insights. From observation and analysis of the Osun case, urban poor, though more inconvenienced with structural changes, also appreciates and values the social, economic and infrastructural advantages of urban renewal. This is more so when certain cushion effects in form of compensation, no matter how little is provided for their immediate indemnity. Thus, from this experience, one can then be speculating a kind of 'interclass mutual-needs and appreciation approach' to urban renewal and development.

\title{
3. Historical development of urban renewal and development in Nigeria: a focus on the case of The State of Osun in Western Nigeria
}

Historically, urban and social segregation policy in Nigeria dates back to the colonial dispensation- Colonial Europe Reservations Policy of 1902, the Township Ordinance of 1917, the Nigerian Town and Country Planning Ordinance of 1946, and was later followed by the National Housing of 1972, the National Housing Policy of 1991 and the Millennium Development Goals adopted by Nigeria (Ugwu 2011; Uyanga 2011). At independence, cities that serve as seat of political administration across different levels of government, necessarily, had to witness some expansion and 
infrastructural enhancement. Ever since then in Nigeria, one form of urban re-planning and renewal has been the hallmark of governance.

Three factors could be identified to have contributed greatly to urban renewal in Nigeria. One, creation of new sets of states through territorial disaggregation, two, election of new party and set of elites into government, and three, need to embark on major environmental and infrastructural development, such as road, rail construction, drainage, airport, markets. However, in Nigeria, just as we observed in rent gap analysis, very often, these developments occur bringing along with it some consequences both positive and negative. On the positive side are: better planned cities, solution to traffic congestion, better environment, better health for the people, reduction in travel times, attraction of new businesses, and overcoming of disorderly and spontaneously created shanties that poses serious security threat to the people and the social systems. On the negative, we have: loss of homes by the poor who are usually neither compensated nor rehabilitated, loss of jobs, inconveniences associated with increased distance between the new found home and the place of work, increased cost of transportation and travelling time for school children, displacement of menial workers, loss of socioeconomic ties by the poor, outright loss of livelihood by some of the 'most poor' families. While in some instances, rehabilitation have occurred in the past, most of such movements across great distance, apart from housing, rarely consider other factors, such as disconnection with their established means of livelihood (official employment) and other social and economic activities, that the displaced individuals required for their continued upkeep. The truncating effect of such displacement lasts for so long on their lives with some parents dying earlier than expected as a result of stress and unending frustration leaving under-aged and dependent children.

Apart from when new cities are created as an aspect of modernization and 'national front office' to disguise national poverty, such as Nigeria experienced in the mid-70s with FESTAC 77, and movement of the Federal Capital to Abuja in the early 90s, most other attempts at bringing about city and urban renewal and re-planning entails untold hardship for the poor. One case in point was the displacement of people at Maroko and Lekki in Lagos in 1992. Agreed these lands might have been acquired by government, but most inhabitants of Maroko and Lekki still had to acquire these lands from the traditional land owners, having to pay sum substantial amount for the land and also to erect houses that were used as dwellings and for businesses of various types. What was known of Maroko was that most of the inhabitants were only given notices to evacuate themselves from these vastly developed and densely inhabited areas. Neither compensation nor all-embracing resettlement alternatives were made available to the inhabitants before bulldozers moved in to destroy their houses and businesses within a period of one week in 1992 only to be gathering whatever was left of their households from the rubbles after their houses and businesses have been pulled down by bulldozers.

Olu Sule noted:

Perhaps the only way to avoid the problem of a reduced housing stock in any urban renewal project, thus curbing the incidence of the spiral process of slums among the poor, as the Maroko example has demonstrated in Lagos, is by building new dwelling units for relocatees before demolishing their present homes. (Olu Sule 1990).

Compounding the plight of the ejected inhabitants of Maroko and Lekki areas, the state institutions that midwived between the ejected occupants and the new occupants, did little or nothing to connect the former to the latter for resettlement aid, or compensation.

In the light of the above, and coupled with the fact that Nigeria, from the onset of the ongoing democratic dispensation in 1999 has witnessed another rounds of massive urban renewal and re-planning with its massive negative implication being more on the poor, it becomes compelling for analysts and social critics, to take interest in studying the effect of modernization as they occur on the lives of the poor. Just as it happened in Maroko, the ongoing urban facelifting in the Federal Capital Territory (FCT) Abuja and other urban centres (Olukoya, et al 2012) are also not without their tales, as houses are being demolished, businesses (mostly of the poor people) terminated or disrupted and families made homeless.

\section{An exception from the uncaring models of urban development and modernization in Nigeria: the ongoing experience in The State of Osun in Western Nigeria}

As will be highlighted hereafter, while development having bearings on environment, particularly developed and functioning cities cannot occur without people still counting some costs, the ongoing urban development and renewal in The State of Osun seems to be adopting measures aimed at averting many of the negative consequences associated with urban re-planning and renewal on 'the poor indeed' in Nigeria. The state government is adopting multidimensional 
measures to cushion the associated negative effects of urban re-development on the poor. Some of the measures that have so far been taken with public awareness are:

\subsection{Attempt at decentralized and state-wide development of socioeconomic infrastructures}

Realizing that massive urban renewal will necessitate some socioeconomic displacement of the poor, the state government is making serious effort at developing across the states, socioeconomic facilitating infrastructures, that could enable people that may be displaced from one form of business or another in the capital city to return to any of their preferred zones within the state to continue with their lives with less difficulties. On this line, while market and business districts are been created across the state, trading activities constitutes logistic problem, such as traffic congestion, security risks, health hazards, and violation of esthetic order of the capital and other cities within the state are been relocated to alternative sites. As step, towards facilitating state-wide socioeconomic interconnectivity and development, existing roads and markets are being rehabilitated and constructed across the state.

\subsection{Compensation for victims of modernization}

Apart from the readiness of the state government to compensate bonafide landlords whose houses or properties may be affected by the ongoing expansion of the existing road network within the state capital and other major cities within the state, the state government is confirmed (by 66 percent of respondents) from a survey conducted among those at the lower rungs of the society in April 2913 to be paying some compensation to cushion the effect of their temporary socioeconomic dislocations.

\subsection{Vocational training for youths and categories of people}

To cater for those who may suffer the loss of one form of business opportunity or another as a result of the development, people are being trained and retrained for some other jobs in areas that have through careful planning and analysis been identified not to have been fully tapped and that are needed for overall socioeconomic development of the State and the nation.

\subsection{Increased state-facilitated agricultural training and activities}

Towards boosting agricultural production, on-the-farm training are currently been planned for existing farmers, while youths and unemployed school-leavers and graduates are being encouraged and trained in various areas of agriculture.

\subsection{Increased emphasis on functional education}

Also, as a way of reducing social menace and unrest, greater emphasis is being given to functional education. This is signified with building of more schools and provision of Opon Imo (Tablet of Knowledge) across the state just as emphasis is given to better technical education to promote self-employment after school.

\subsection{Health-related services}

Apart from efforts at improving environmental conditions across the state, at present, the state government supplies medications to public hospitals which are given to patients free of charge to cover at least the treatment of primary ailments. Also, while there is a considerable increase in road repair and maintenance across the state, emergency services are provided with state-run ambulances and paramedics on most highways to provide first aid to accident victims.

Of all the strides so far recorded by the Osun State Government, one stands out as exception from the history of development in Nigeria. Response to various qualitative survey questions conducted in the month of April 2013, using purposive random sampling among people in the selected areas where there has been some measured demolition of houses, shops and business centres within Osogbo metropolis, the capital of The State of Osun, were quite revealing of public and interclass appreciation of the programme. The questions covered five major themes: (1) Effect of the ongoing urban renewal programmes (about 89 percent of respondents claimed they were affected one way or the other by the 
ongoing programmes), (2) Ameliorative measures (not less about 66 percent of respondents claimed to have received some compensation), (3) Information flow (71 percent claimed they were given prior information about how they were likely to be affected, (4) Policy and General Advice, (Up to 49 percent of the affected respondents want the Government to continue with such programmes) and (5) General Assessment of the programme (over 70 percent of the affected respondents sees the development as good)

From the above abridged simple percentage analysis, while there are negative views, which altogether, is not unexpected for most government programmes, it is evident that the ongoing urban renewal and transformation in the state of Osun is a popular programme. This supports our proposition for 'interclass mutual needs and appreciation approach' to development insisting that both the rich and the poor can agree on certain programmes of development that caters for their mutual needs and interests not withstanding differing degrees of inconveniences.

While, the survey records a considerable acknowledgement of compensation, it is noted that not all affected victims were compensated. Also, seeming equalization of most categories of compensation failed to provide opportunity for determining and awarding commensurate indemnity for victims. It is noted from this research, where the government do not suffer from the usual disease of disguised 'motives of the cult of the elite', that the Government of the State of Osun is striving towards improved mass-oriented economic development of the state. The end-product will be historically unparalleled achievements that will further endear the government and its programme to the people. With measured inconveniences, there is a general acceptance and appreciation of the ongoing transformation. While there are genuine critical views (see Nigerian Tribune online, Osun and the challenge of urban renewal, sourced from: http://tribune.com.ng/index.php/features/51395-osun-and-the-challenge-of-urban-renewal on 22 June 2013), some are suspected to have been more influenced by either none or inadequate receipt of compensation, and more importantly, by political affiliation. On the whole, this experience can best be described as 'progress assured with the least possible unavoidable pains'.

\section{Urban renewal, welfare of the poor and further steps to mitigate social cost of development: lessons from the State of Osun}

While as in the case of The State of Osun, as it has never been the case before now in Nigeria, certain positive measures have been adopted to cushion the effect of urban renewal on the poor, other measures considered necessary but yet not taken by governments in Nigeria generally to reduce the social cost of development, particularly as it related to the poor, includes the following:

- Government land laws should be made clear and public awareness constant.

- As observed in the case of Maroko, Lekki and their adjoining towns, networking the displaced and the new acquirees of the recovered plots should be given consideration.

- In this modern era, there should be dispassionate analysis of public urban needs. Increased official attention should be given to city and national planning to avoid unnecessary social disruptions.

- Unsuspected demographic estimation should precede every urban renewal to estimate the 'opportunity social cost' of development and forestall situations in which genuine victims are not covered in the administration of commensurate compensation benefits.

- Allocation and enjoyment of rehabilitative amenities such as market stalls, shops, farm plots and others should be liberalized and no form of cartelization should be encouraged. Beyond the roles of house rental agents, tenants/rental advocacy should be encouraged. This will help prospective tenants (dwellings and businesses) to ascertain the legal status of the properties in which they seek to live or establish their businesses.

- Demographic statistics should in addition provide facts about the categories of victims and their possible alternate negative predispositions- prostitution for homeless and jobless girls, crimes for boys, shock and health hazards for adults and aged, separation and break-up for average poor families and homes for official proactive mitigating measures.

- Following the example of The Redeemed Church, where existing land facilities in established areas are exhausted, rather than forcefully eject those that have naturally and inadvertently evolved with existing fully grown public and business centres, government should embrace the idea of establishing new towns and business zones in less or rarely inhabited virgin lands. 


\section{Conclusion}

Urban renewal is a welcome development in every modern society. It however should be realized that to promote genuine development, every public programme should embrace 'interclass mutual needs and appreciation approach' embedding some measures of assured benefits for all categories of people. Just as the spiral effects mostly affect the poor in the long run, their welfare and commensurate programme of assistance should always be a constant on the mind of the governing elites and on the agenda of government as the representatives of the people. This becomes necessary as the poor is, in the generality of the developing world and sub-Sahara Africa, the harbinger of democratic rules and assured platform of its social capital and sustenance.

\section{References}

Atkinson, Rowland and Gary. Bridge, eds. 2005. Gentrification in a Global Context: the New Urban Colonialism, Routledge p. 5.

Attoh, Franca. 2012. Chattels of their families: trafficking of young women as gender violence, sourced from: http://www.codesria.org/IMG/pdf/Franca_Attoh.pdf on 6 July 2013.

Booza, Jason. C., Cutsinger, J, and G, George. 2006. Where Did They Go? The Decline of Middle-Income Neighborhoods in Metropolitan America, Metropolitan Policy Program, Brookings Institution, Living Cities Census Series, June

Cohen, M. A. 2011. Urban Policy and Political Conflict in Africa, Chicago: University Press.

Friedman, John. 1986. "The world-city hypothesis." Development and Change (SAGE, London, Beverly Hills and New Delhi), Vol. 17. 69-83

Green, J. O. 2011. Urban Administration and Development, London: Free Press.

Lees, Loretta, Tom Slater, and Elvin Wyly. 2008. Gentrification Reader, Routledge. 196.

Maureen Kennedy and Paul Leonard. 2001. Dealing with Neighbourhood Change: A Primer on Gentrification and Policy Choices.

Nigerian Tribune online, Osun and the challenge of urban renewal, Sourced from: http://tribune.com.ng/index.php/features/51395-osunand-the-challenge-of-urban-renewal on 22 June 2013

Olawepo, R.A. 2008, Perspectives on Urban Renewal and Transportation Development in Lagos: Implications for Urban Development, in Nigeria African Journals Online. 273-287.

Olu Sule R. A. 1990. Recent slum clearance exercise in Lagos (Nigeria): victims or beneficiaries? GeoJournal, Springer: Volume 22, Issue 1. 81-91. September.

Olukoya, Y. et al 2012. "Rage of bulldozers : South-West's year of demolition", Tribune, Sunday, 30 December. Sourced from http://www.tribune.com.ng/news2013/index.php/en/component/k2/item/1999-rage-of-bulldozers-\%E2\%80\%A2-southwest $\%$ E2\%80\%99s-year-of-demolition on 22 June 2013

Paul L. Knox and Peter J. Taylor, eds. 1986. From World Cities in a World-System, Cambridge UP, 1995. 317-331. (originally published 1986)

Palen, J. John and Bruce London. 1984. Gentrification, Displacement, and Neighborhood Revitalization, America: State University of New York Press

Sakia, Sassen. 1991. The Global City: New York, London, Tokyo (Princeton: Princeton University Press, 1991) 1st edition

Sakia, Sassen. 2001. The global city, New York, London, Tokyo (Princeton : Princeton University Press, updated 2d edition.

Sanni, O. 2010. "Management of Private/Public Partnership in Reviving the Nation's Infrastructure," in NIM, Managing our Future Today. Journal of the Nigerian Institute of Management. Lagos: NIM.

Siemens. 2013. http://www.siemens.co.za/sustainable-development/sustainable-development.html?stc=ngccc020017 on 22 June 2013

Smith, N. 1987. "Gentrification and the rent-gap", Annals of the Association of American Geographers 77 (3) pp. $462-465$.

Udenta, N.O. 2011. Urban Development in Nigeria. Lagos: Longman Press.

Ugwu, S. C. 2011. "Issues in Local Government and Urban Administration," Enugu: Echrisi and Company.

Umali-Deininger, D. 2011. "Public and Private Agricultural Extension: Partners or Rivals," Research Observer, Washington, D.C.: The International Bank.

US Centers for Disease Control and Prevention[12]

Uyanga, J. 2011. "Toward the National Urban Policy," Ibadan: University Press. 